\title{
Nematode Management in Organic Agriculture ${ }^{1}$
}

\section{Romy Krueger and Robert McSorley²}

Nematodes are usually microscopic in size and are classified as unsegmented worms, belonging to the Phylum Nematoda (Figure 1). Plant-parasitic nematodes are a concern for growers of agricultural or garden crops. These plant-parasitic nematodes will mainly feed on the roots of plants. A few kinds will feed on foliage but this not common. Many other kinds of nematodes are present in the soil as well. These include decomposers, predators, insect parasites, and animal parasites. Some nematodes are aquatic and do not affect terrestrial plants. Other nematodes act as decomposers, predators, and insect parasites. In farming systems, nematode predators and parasites of insects are beneficial, while nematode parasites of animals and plants are considered pests in agriculture. Beneficial nematodes that feed on either bacteria or fungi help in nutrient cycling by accelerating the decomposition of organic matter (Figure 2). Predatory nematodes may keep harmful nematodes at lower levels by feeding on them. Entomopathogenic nematodes (nematodes harmful to insects) may help to reduce numbers of some insect pests by infecting them with bacteria. The objectives of this publication are to provide information on plant parasitic nematodes causing damage in organic agriculture and to introduce methods for their management.

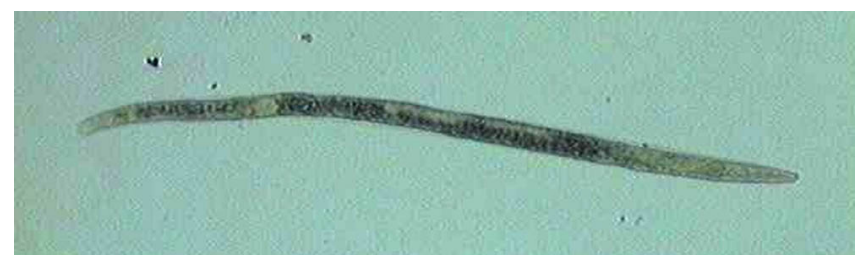

Figure 1. A typical plant parasitic nematode.

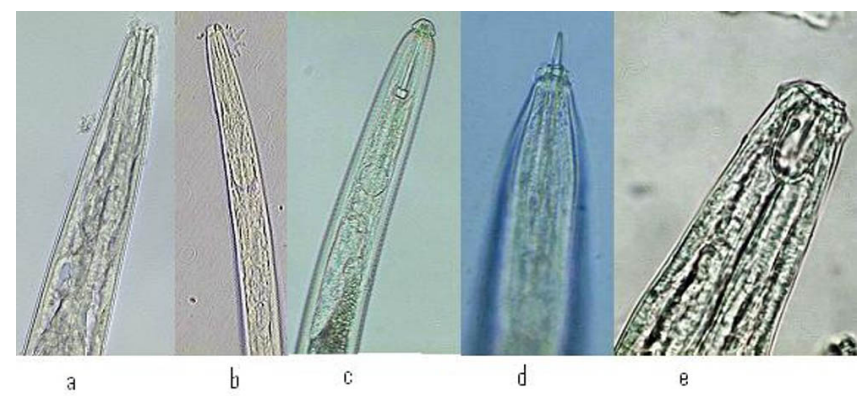

Figure 2. Different nematodes: a) Bacterivore, b) Fungivore, c) Herbivore, d) Omnivore, e) Predator

\section{Nematode Damage and Detection}

Since most plant-parasitic-nematodes feed on plant roots, symptoms are comparable to nutrient or water deficiency. These can be yield loss, stunting (Figure 3), yellowing, wilting, symptoms of nutrient deficiency, and malformations of the root (including tubers, peanuts) caused by direct feeding damage. In addition, invasion by plant-parasitic nematodes often

1. This document is ENY-058 (NG047), one of a series of the Entomology \& Nematology Department, Florida Cooperative Extension Service, Institute of Food and Agricultural Sciences, University of Florida. First published: January 2008. Reviewed March 2011. For more publications related to horticulture/agriculture, please visit the EDIS Website at http://edis.ifas.ufl.edu/.

2. Romy Krueger, graduate assistant, and Robert McSorley, professor, Entomology and Nematology Department, Institute of Food and Agricultural Sciences, University of Florida, Gainesville, FL, 32611.

The Institute of Food and Agricultural Sciences (IFAS) is an Equal Opportunity Institution authorized to provide research, educational information and other services only to individuals and institutions that function with non-discrimination with respect to race, creed, color, religion, age, disability, sex, sexual orientation, marital status, national origin, political opinions or affiliations. U.S. Department of Agriculture, Cooperative Extension Service, University of Florida, IFAS, Florida A. \& M. University Cooperative Extension Program, and Boards of County Commissioners Cooperating. Millie Ferrer-Chancy, Interim Dean 
provides an infection route for other organisms such as bacteria or fungi, since nematode activity creates an entryway into the root that would otherwise not be available. Nematode reproduction is very fast. On average, a typical life cycle may be only 30 days at summer temperatures. This means that even if nematode numbers are low at the beginning of the growing season, nematode populations can rapidly increase and can become harmful to the crop in a relatively short period of time.

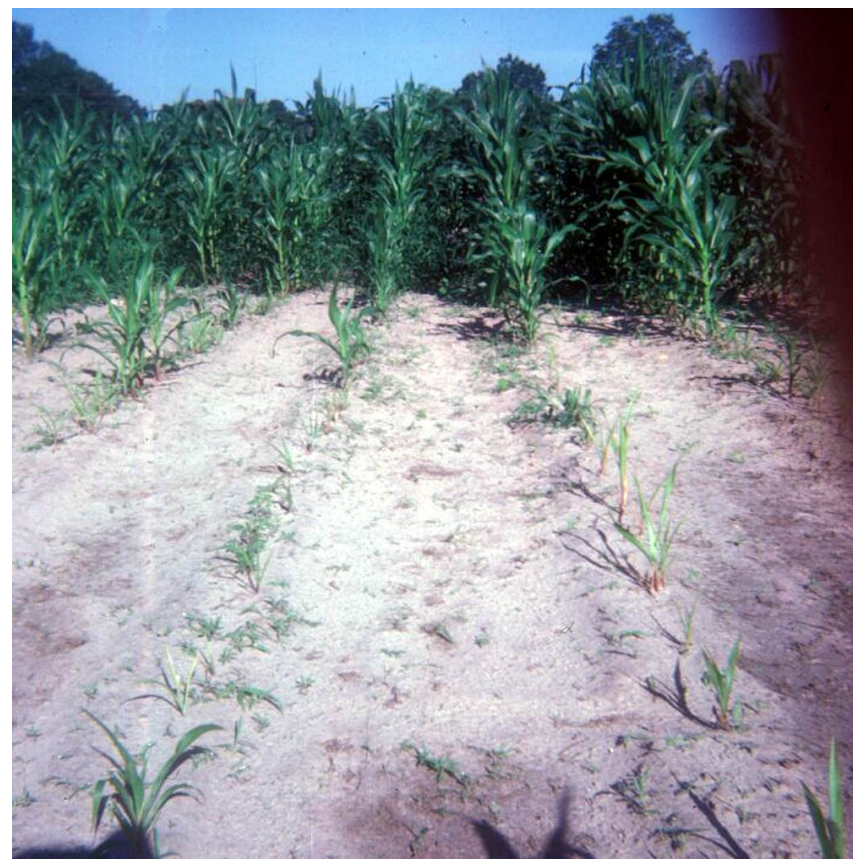

Figure 3. Symptoms caused by plant parasitic nematodes: severe stunting in corn.

Often, the most damaging nematodes in the southeastern United States and the tropics are root-knot nematodes (Meloidogyne spp.). These nematodes are pests of nearly all major crops and are therefore widespread. Damage can be directly observed by examining the roots, because root-knot nematodes produce galls or knot-like swellings along the plant roots (Figure 4). These galls cannot not be easily removed because they are part of the plant root tissue. In contrast, nodules caused by beneficial nitrogen fixing bacteria can be easily removed. Another method to distinguish nematode galls from nodules is to slice them in half and expose to air, which will cause nitrogen-fixing nodules to appear pink or red if the bacterial colony is active, or green or brown if the colony is inactive.

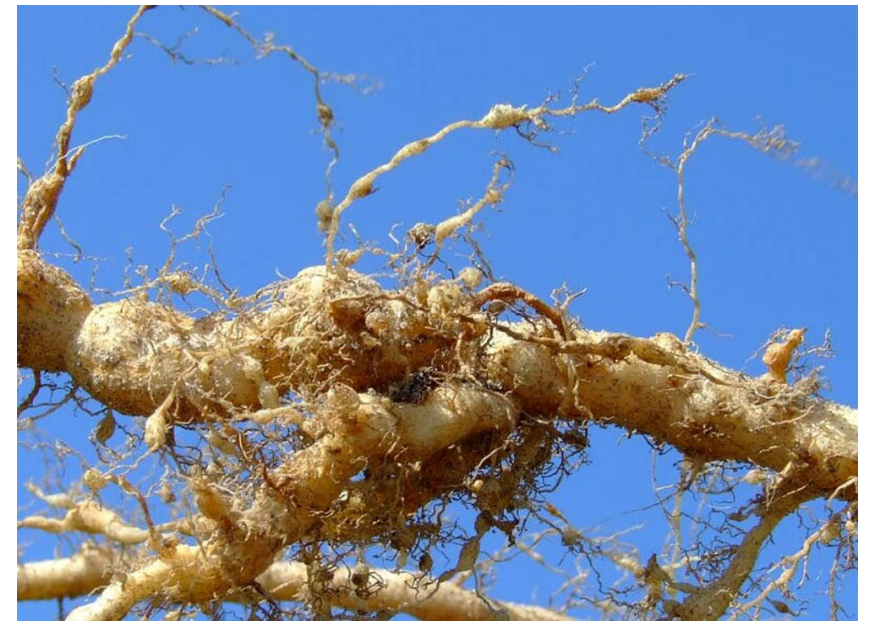

Figure 4. Root galls caused by root-knot nematodes.

Evidence of direct feeding, apparent in the form of galls and other root malformations leads to the damage symptoms described above. The invasive stage of the root-knot nematode life cycle is the juvenile root-knot nematode, which can freely move through the soil and will enter the root of a suitable host plant. Only the female is capable of establishing a feeding site. The female will become immobile, causing the plant to form giant cells for feeding, which essentially appears as a gall on the root. The presence of root-knot nematodes can be detected by the presence of these characteristic galls.

Soil Samples. Other plant-parasitic nematodes do not cause these gall symptoms, and so soil samples should be taken to determine which nematodes are present in a field. Even when it is clear that root-knot nematodes are to blame for the damage caused, it may be beneficial to find out if other nematodes are present to determine which treatments should be employed and will work best.

For further information on taking soil samples and where to send them, please refer to the EDIS publication "Nematode Assay Laboratory" at http://edis.ifas.ufl.edu/SR011 (Crow and Woods 2007).

\section{Nematode Management}

In nematode management it is important to remember that nematodes can move only very short distances on their own. Therefore nematodes are mainly spread through lack of sanitation and movement of infected soil and planting material. In 
order to limit a build-up of nematodes, planting equipment and tools should be properly cleaned, and in extreme cases could only be used for the same field. Furthermore only soil and planting material free of nematodes should be used, because once nematodes are introduced into a field they cannot be eradicated. After harvest infected plants should be destroyed to prevent the build-up of nematodes on these crop residues and therefore in the soil. Once they become established in a site, the nematodes will persist there, and management will be required on a regular basis.

\section{Resistant Plants and Rotation Crops.}

Nematode management is primarily a pre-planting activity. In order to protect the crop most activities must be started two or three months before the scheduled planting date. Several pre-plant treatments are available for the organic farmer. The choice of a suitable crop cultivar can be a critical decision. Host plant resistance achieved by traditional breeding programs can be a valuable protection against some nematodes.

Two terms that are often used when talking about host plant resistance to nematodes are "tolerance" and "resistance." Tolerance means that the plant can withstand some damage caused by nematodes without experiencing significant yield reduction. In contrast, resistance means that nematode reproduction is very low or non-existant on the plant. Both provide protection for the crop plant, but the next crop following a tolerant plant could be damaged by the nematodes that survived on the tolerant plant. Different plant species or even cultivars of the same plant species can exhibit varying degrees of resistance or tolerance. According to the University of Missouri-Columbia extension service, the following vegetable plants are recommended as reasonably resistant to root-knot nematodes: broccoli, brussel sprouts, mustard, chives, cress, garlic, leek, groundcherry, and rutabaga (Donald 1998). In contrast, Globe artichokes, Jerusalem artichoke, asparagus, sweet corn, horseradish, some lima bean varieties, onion, and rhubarb are considered to be tolerant. However, the Alabama Cooperative Extension System provides additional information on resistant crops (Hagan et al. 1998). Cowpea (Figure 5) or black-eyed peas, which can be used as a rotation crop to reduce nematode numbers, has several cultivars that are quite different in their ability to support reproduction of the root-knot nematode Meloidogyne incognita. Planted into the sandy soils of Florida, the cultivars Tennessee Brown, Mississippi Silver, and California Blackeye \#5 inhibited reproduction more effectively than the cultivar Purple Knuckle (intermediate). Population densities were high after planting the cultivars Whippoorwill, Pinkeye Purplehull, and Texas Purplehull (Gallaher and McSorley 1993). Iron Clay is another cowpea cultivar that is known to reduce population levels of $M$. incognita (McSorley 1999).

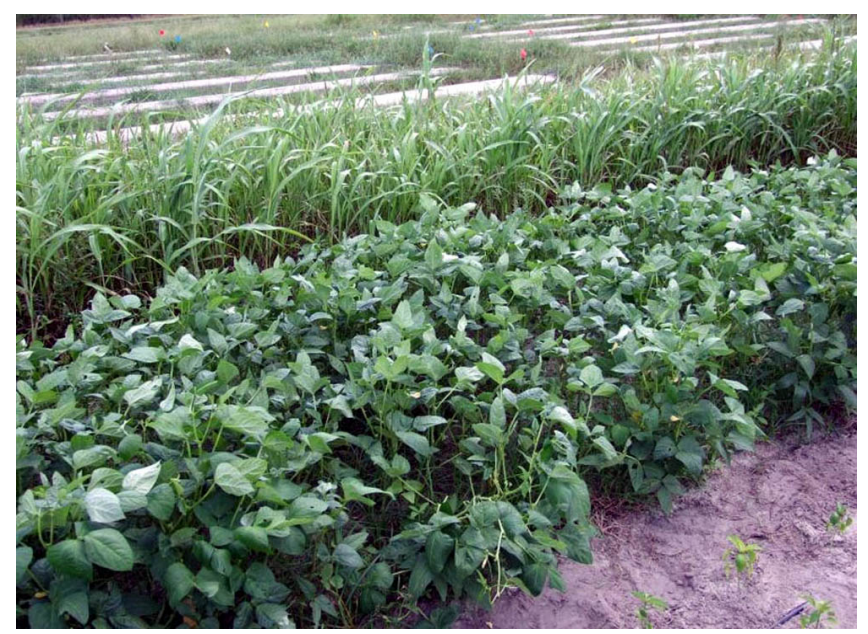

Figure 5. Cowpea with young sorghum $x$ sudangrass in the back.

Crop rotation utilizes crops that are a poor or non-host to the nematodes found in an agricultural field. These crops can either be plants that provide a secondary cash crop grown in between cycles of the primary cash crop, or they could be cover crops that are not primary but provide benefits to the farming system such as nitrogen enrichment, nematode reduction, or possible additional income. In either case, nematode numbers are reduced simply because nematodes are deprived of a suitable host crop. This does not mean that nematode densities are reduced indefinitely, but a successful crop rotation should reduce nematode levels enough so that a following susceptible crop will produce sufficient yields and survive until the end of its regular growing season. Popular cover crops are sorghum, sorghumsudangrass (Figure 6), different grains such as oat and rye, many grasses, marigold, cowpea (Figure 5), 
and some tropical legumes such as sunn hemp (Crotalaria juncea, Figure 7) and velvetbean (Mucuna spp.). These cover crops are useful to reduce root-knot nematode population densities. Table 1 lists cover crops, which demonstrated low or intermediate susceptibility to $M$. arenaria race $1, M$. incognita race 1, and M. javanica (McSorley 1999, McSorley and Dickson 1995, McSorley et al. 1994, Krueger et al. 2007). Even though these cover crops are effective against root-knot nematodes, they might increase other harmful plant-parasitic nematodes that are also present in the soil. For example, densities of the sting nematode (Belonolaimus longicaudatus) and stubby-root nematode (Paratrichodorus minor) increased on SX-17 sorghum-sudangrass. Mississippi Silver cowpea was able to reduce $P$. minor and $M$. incognita but increased B. longicaudatus. The most effective cover crop that simultaneously reduced root-knot, stubby-root, and sting nematodes was determined to be velvetbean (McSorley and Dickson 1995). Results vary in different locations as well. In Kenya, a plant related to sunn hemp (C. ochroleuca), which successfully reduced populations of root-knot nematodes appeared to increase the occurrence of lesion nematodes (Pratylenchus zeae), whereas jack bean (Canavalia ensiformis), hyacinth bean (Lablab purpureus), and velvet bean appeared to reduce both nematodes (Arim et al. 2006). Response of nematodes is greatly influenced by the cultivar of a crop plant species. Therefore even if the same plant species is used, results may vary if the cultivar is different. Sorghum is often recommended as a cover crop to decrease population levels of root-knot nematodes, and is widely used for this purpose (Dover et al. 2004). However, use of an uncommonly used cultivar (Asgrow Chaparral) actually increased population levels of root-knot nematodes $(M$. incognita) in a field experiment in North Florida (McSorley and Gallaher 1992). Furthermore, reactions of plants seem also to be site dependent. Cover crops that decrease nematode populations in one field may not be effective in another, depending on local nematode species and their local populations and variants present. Since weeds can harbor nematodes, it is important to have a dense cover crop stand that blocks out weeds. For more comprehensive information, please refer to the publication of the Sustainable Agriculture Network on cover crops (Bowman et al.2007).

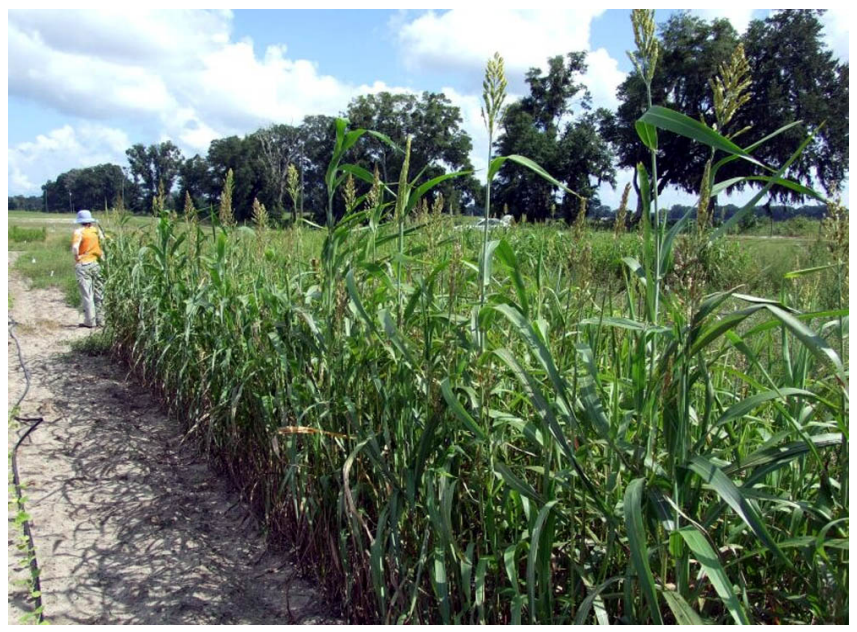

Figure 6. Mature sorghum x sudangrass.

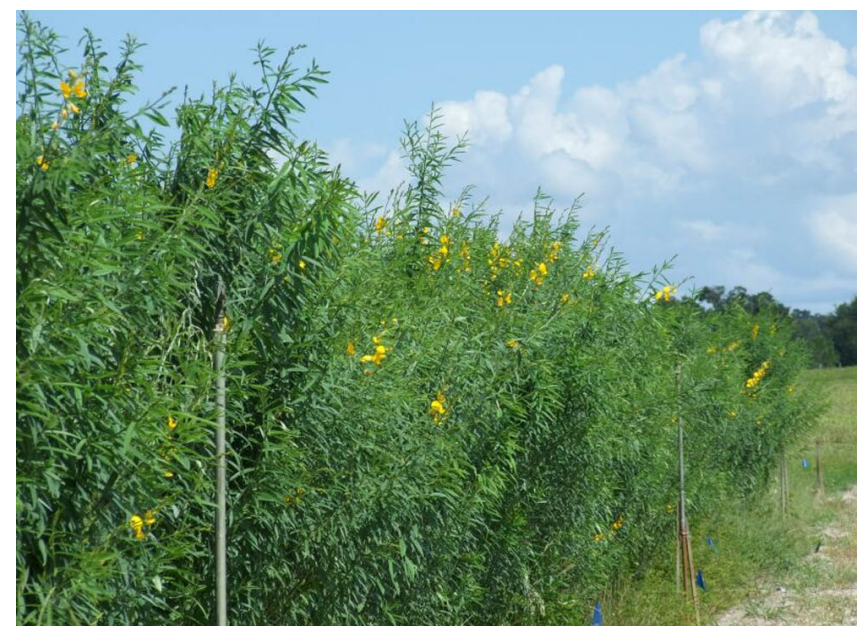

Figure 7. Sunn hemp starting to show flowers.

Tillage. Tillage and the practice of fallowing fields may appear as alternatives to cover crops for nematode management. Tillage inverts and mixes soil and exposes deeper soil layers to the sun. This practice is meant to kill nematodes by desiccation, since nematodes depend on moisture for survival. This practice may kill some of the nematodes that are in the upper soil layers, however it will not reach nematodes that have retreated into moderate or deeper soil layers. Nematodes can retreat to depths greater than 12 inches $(30 \mathrm{~cm})$ in Florida soils, and can migrate upward once a susceptible host is planted. Once a field has been fallowed, nematodes will move into deeper soil layers to avoid drying and may enter an inactive stage that enables them to survive periods without food and in addition protects them from desiccation. McSorley and Gallaher (1993) compared the effects of tillage versus crop rotation on nematode densities in tropical corn (Zea 
Table 1. Cover crops, which demonstrated low or intermediate susceptibility to $M$. arenaria race $1, M$. incognita race 1 , and M. javanica (McSorley 1999, McSorley and Dickson 1995, McSorley et al. 1994, Krueger et al. 2007).

\begin{tabular}{|c|c|c|}
\hline Common Name & Scientific Name & Cultivar \\
\hline \multirow[t]{2}{*}{ cowpea } & V. unguiculata & 'Mississippi Silver' \\
\hline & & 'Iron Clay' \\
\hline sunnhemp & Crotalaria juncea & \\
\hline American jointvetch & Aeschynomene americana & \\
\hline \multirow[t]{2}{*}{ marigold } & Tagetes minuta & \\
\hline & T. patula & 'Dwarf Primrose' \\
\hline velvetbean & Mucuna deeringina & \\
\hline sorghum-sudangrass & Sorghum bicolor $x$ S. sudanese & 'SX-17' \\
\hline jack bean & Canavalia ensiformis & \\
\hline partridge pea & Cassia fasciculata & \\
\hline \multirow[t]{2}{*}{ sesame } & Sesamum indicum & 'Sesaco 16' \\
\hline & & 'Paloma' \\
\hline
\end{tabular}

mays) cultivar Pioneer X304C in North Florida. Tillage did not have significant effects on nematode densities, while a rotation crop of sorghum cultivar DeKalb BR64 reduced population levels of root-knot nematodes $(M$. incognita). These results demonstrate that tillage is not a reliable method for nematode management in Florida. Fallowing can deprive nematodes of food, if the field is kept $100 \%$ weed free, and therefore can reduce population levels. But clean fallowing is a poor practice for soil conservation and nutrient runoff. In the absence of plants that keep soil in place, wind will be able to carry some of the topsoil away. Additional soil will be lost with rainwater runoff. Rain will also carry soil nutrients into lakes and rivers, which will degrade water quality and interfere with aquatic ecosystems.

Solarization. A promising technique is the use of heat to decrease not only nematode densities, but also other harmful organisms and weed seeds. This can involve pasteurization, steaming, or solarization of the soil before planting. Of these, solarization is probably the most practical (Figure 8). It involves the covering of the soil with clear plastic. Transparent plastic sheets allow short-wave radiation from the sun to penetrate the plastic. Once the light passes through the plastic and is reflected from the soil, the wavelength becomes longer and cannot escape through the plastic. The trapped light facilitates heating of the soil to temperatures detrimental to most living organisms. There are different types of plastic sheets available, mainly differing in their thickness (insulation) and ability to let light through (transparency). Black, opaque, or translucent plastics are not suitable for solarization. Thin, transparent plastic sheets appear to achieve the best results. Katan (1981) recommended thicknesses between 25 to 30 $\mu \mathrm{m}$. Temperatures can rise anywhere between 35 and $60 \mathrm{C}(95-140 \mathrm{~F})$ during the summer months (Katan 1981, Stapleton 1991) when air temperatures are close to $32 \mathrm{C}(89.6 \mathrm{~F})$ or higher. However, cloud cover and rain limit solar radiation and may diminish 
the success of solarization (DeVay 1991, Katan 1980). Soil temperatures only rise to detrimental levels in the first 10 to $30 \mathrm{~cm}$ of soil (Katan 1987), and even in this range temperatures drop off as depth increases. The plastic has to be sealed to prevent air movement underneath the plastic, which would prevent temperatures from rising sufficiently.

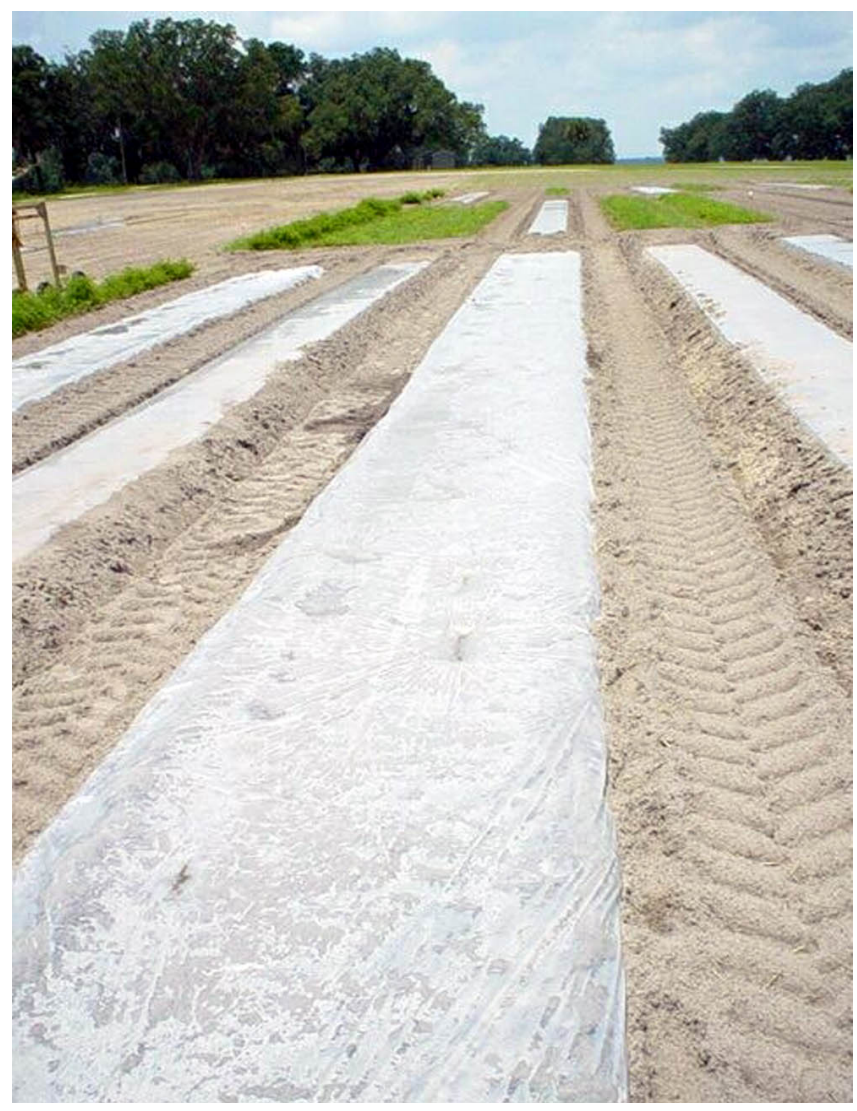

Figure 8. Solarization.

The soil should remain covered for a minimum of four weeks, but increasing solarization time improves effectiveness. This helps to heat the soil at a greater depth, which means that more nematodes will be affected by it (McGovern and McSorley 1997). Furthermore it also ensures that an adequate accumulation of solarized hours is achieved, which is important in regions like Florida where the sky is often overcast during the summer months.

A combination of a suitable cover crop and solarization seems to achieve best results. Wang et al. (2006) showed that following a cowpea cover crop with solarization accomplished better results than solarization alone. In fact, the effectiveness of this combined treatment was comparable to methyl bromide fumigation, which in conventional agriculture was the most effective treatment used against soil-borne diseases and pests. The disadvantage of solarization is its negative impact on beneficial soil organisms, since they will meet the same fate as their harmful counterparts. But recovery is usually attained quickly through rapid recolonization. Furthermore, other beneficials such as Bacillus, Pseudomonas, and Trichoderma are able to survive the high temperatures generated by solarization (Katan 1987). Solarization generates considerable plastic waste, which, when farming with a sustainable approach in mind, is a drawback. However, plastic sheets could be used multiple times.

Biological Control. Biological control is the management of plant-parasitic nematodes by living organisms such as bacteria, fungi, predatory nematodes, or other invertebrates. Biological control is mainly accomplished by attempting to build-up beneficial organisms through the use of various soil amendments. The introduction of beneficial soil organisms to the soil has only been attempted successfully in a few instances. Pasteuria spp., which are bacterial parasites of various plant-parasitic nematodes occurring naturally in Florida soils, may be promising biological control agents. In a 7-year experiment with tobacco, Weibelzahl-Fulton et al. (1996) showed that M. incognita and M. javanica were suppressed exclusively by $P$. penetrans. Tobacco plants treated with $P$. penetrans had fewer galls, egg masses, and eggs than plants that either did not receive $P$. penetrans or lacked the biological control agent due to autoclaving the soil in which the plants were grown. Nematode-trapping fungi are also potential candidates for biological control (Wang and McSorley 2003). Their adhesive knobs, rings, or net structures trap nematodes and kill them. Other types of fungi may parasitize nematode eggs. Neither fungi nor Pasteuria spp. are available for widespread commercial use at this moment. But they can be found in a healthy soil environment, as can predators such as mites and predatory nematodes. Recent research has shown that a wide range of nematode natural enemies occur in Florida soils (McSorley et al., 2006). Most predators are generalists, meaning they feed on a variety of prey species during their lifetime. For biological control purposes, generalist predators are a disadvantage, because they will not only feed on the key pest, but on other suitable 
organisms as well including beneficials. Furthermore if there is not enough food available they will disperse, possibly causing the pest to rebound. On the other hand, generalist predators can keep many different kinds of pests at low population densities. Currently, no predators are commercially available for augmentive releases for nematode control in vegetable production systems.

\section{Organic Amendments in Relation to Biological Control}

Biological control is difficult in soil, because it is a complex environment. Many of the possible organisms that could provide biological control lack specificity and therefore will not focus on a particular organism and may even interfere with beneficials. Therefore biological control of nematodes is achieved mainly by conservation of existing biological control; meaning that the soil environment is modified to aid the survival and reproduction of nematode natural enemies that are already present. Primarily this is accomplished through the addition of organic amendments (Figure 9). Organic amendments can improve the soil environment to aid biological control, benefit general plant health by helping with water retention and providing additional nutrients, and affect nematodes directly and negatively through detrimental decomposition products. The impact of organic amendments on nematodes is often inconsistent and unpredictable. In most cases when organic amendments are applied, they are helpful mainly as a plant nutrient source and do not directly aid in nematode management. However, even if nematodes are unaffected by the added amendments, plant health may improve due to other favorable properties of amendments. McSorley and Gallaher (1995) observed that amendments consisting of yard waste compost (four to six-month-old wood fragments, leaves, grass clippings) used as mulch or incorporated into the soil improved yield of squash and okra even though plants experienced heavy galling. Although nematode densities in composted treatments were similar to those in non-amended soil plants benefited greatly from the improved retention of soil moisture. Kimpinski et al. (2003) showed similar results. Amendments (compost and manure) increased yield in barley and potatoes in Canada, but this was not necessarily due to reduced nematode numbers.

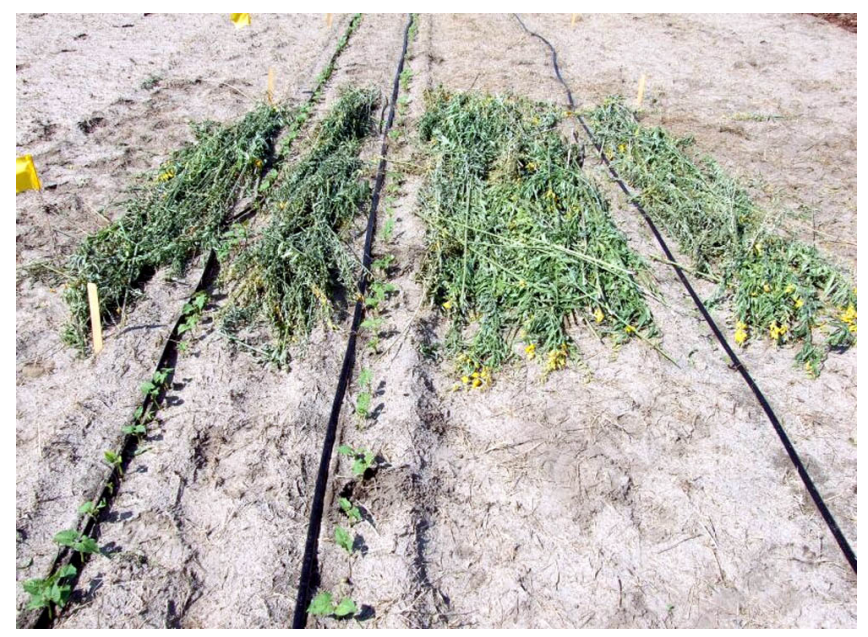

Figure 9. Organic amendments: Sunn hemp mulch applied to beans.

The addition of organic amendments may stimulate the entire soil food web, including beneficial biological control organisms. When soil is amended with nutrient-rich organic matter, microorganisms may immobilize the released nutrients (Swift et al. 1979). Free-living nematodes that feed on these bacteria and fungi may play an important role in the release of nutrients tied up in such a way (Ingham et al. 1985). Soil-inhabitating microorganisms and nematodes therefore may act together to influence the rate of decomposition and release of nitrogen from crop residues, including nitrogen-rich leguminous crops like sunn hemp. Wang et al. (2004) investigated effects of sunn hemp decomposition on the soil nematode community. Litterbags that allowed nematodes to pass in and out were filled with sunn hemp hay and buried in soil. Periodic analysis of the bags showed that sunn hemp decomposition was fairly rapid and most was completed within two weeks. Population densities of nematodes feeding on bacteria increased greatly during decomposition, and this was followed by an increase in omnivorous nematodes that fed on them. However, plant-parasitic nematodes were neither affected by the sunn hemp decomposition nor by the omnivorous nematodes. In fact, plant-parasitic nematode numbers increased over time with increasing crop biomass, which may indicate that sunn hemp residue does not have a direct detrimental effect on plant-parasitic nematodes. In another recent 
study, Chellemi (2006) used urban plant debris (green waste from public landfill deposited by homeowners and landscape companies) to amend pepper fields in southeast Florida. As a result, the combined density of plant-parasitic nematodes was reduced, and other disease-causing plant pathogens (Pythium spp. and Phytophthora spp.) were reduced as well. These examples illustrate the potential use of organic amendments for direct or indirect management of nematodes, but they also indicate that outcomes can be complex and unpredictable.

\section{Management of Infected Plants}

Once plants are infected with nematodes, there is little that can be done to remove or reduce nematodes. Therefore, prevention and sanitation are critical to controlling nematodes. The improvement of plant health is an important cultural technique to lessen detrimental effects on plants caused by plant-parasitic nematodes. Proper irrigation, fertilization and organic amendments as surface mulches or soil incorporated are important. Furthermore, removal of weed hosts and old crop plants immediately after harvest can reduce nematode densities for the future. Nematodes are a long-term pest, which cannot be eradicated once they become established in a site. They can only be kept at low levels with carefully selected management tactics that are often specific to the managed site.

There are a variety of additional methods that may have some effect on nematodes. These include methods such as use of rhizobacteria, chitin, sesame residues, flooding, or microwave energy. Some of these (flooding, microwaving) may be restricted to specialized situations. Performance of these methods may be inconsistent or ineffective in some situations. Amendments such as chitin or sesame residue may provide nutrients that are beneficial to overall plant health regardless of any effects on nematodes. In these cases only small test areas should be subjected to new materials to determine their effectiveness under local conditions. Many of the methods described above such as host plant resistance and rotation are more dependable under a variety of conditions.

\section{References}

Arim, O.J., Waceke, J.W., Waudo, S.W., Kimenju, J. W. 2006. Effects of Canavalia ensiformis and Mucuna pruriens intercrops on Pratylenchus zeae damage and yield of maize in subsistence agriculture. Plant and Soil 284:243-251.

Bowman 2007.SARE. Managing Cover Crops Profitably, Sustainable Agriculture Network, Handbook Series Book 3, National Agricultural Library, Beltsville, MD, $3^{\text {rd }}$ edition. A. Clark, ed. http://www.sare.org/publications/covercrops/ covercrops.pdf accessed 12-10-2007.

Chellemi, D.O. 2006. Effect of urban plant debris and soil management practices on plant parasitic nematodes, Phytophthora blight and Pythium root rot of bell pepper, Crop Protection 25: 1109-1116.

Crow, W.T., Woods, F.E. 2007. Nematode Assay Laboratory, ENY-027 (SR011), Entomology \& Nematology Department, Florida Cooperative Extension Service, Institute of Food and Agricultural Sciences, University of Florida. http://edis.ifas.ufl. edu/SR011 accessed 12-10-2007.

DeVay, J.E. 1991, Historical review and principles of soil solarization, chap. 2 In: Soil Solarization, DeVay, J.E., Stapleton, J.J., and Elmore, C.L., Eds., FAO Plant Production Paper 109, FAO, Rome.

Donald, P. 1998. Managing Nematodes in Gardens, Horticultural MU Guide-Vegetables, Outreach \& Extension University of Missouri-Columbia G 6204 http://extension.missouri.edu/explorepdf/agguides/ hort/g06204.pdf accessed 08-30-2007.

Dover, K., Wang, K.-H., McSorley, R. 2004. Nematode management using sorghum and its relatives. ENY-716, EDIS, Florida Cooperative Extension Service, University of Florida, Gainesville, FL. http://edis.ifas.ufl.edu/IN531 accessed 09-19-2007.

Gallaher, R.N., McSorley, R. 1993. Population densities of Meloidogyne incognita and other nematodes following seven cultivars of cowpea. Nematropica 23: 21-26. 
Hagan, A., Gazaway, W., Sikora, E. 1998. Nematode suppressive crops, Alabama Cooperative Extension System (Alabama A\&M University and Auburn University) ANR-856 http://www.aces.edu/pubs/ docs/A/ANR-0856/ accessed 08-30-2007.

Ingham, R.E., Trofymow, J.A., Ingham, E.R., Coleman, D.C. 1985. Interactions of bacteria, fungi, and their nematode grazers: effects on nutrient cycling and plant growth. Ecological. Monographs 55: 119-140.

Katan, J. 1980. Solar pasteurization of soils for disease control: status and prospects. Plant Disease 64: 45-54.

Katan, J. 1981. Solar heating (solarization) of soil for control of soil borne pests. Annual. Review of Phytopathology, 19: 211-236.

Katan, J. 1987. Soil solarization, In: Innovative Approaches to Plant Disease Management, Chet, I., Ed., John Wiley \& Sons, New York, p. 77.

Kimpinski, J., Gallant, C.E., Henry, R., Macleod, J.A., Sanderson, J.B., Sturz, A.V. 2003. Effect of Compost and Manure Soil Amendments on Nematodes and on Yields of Potato and Barley: A 7-Year Study. Journal of Nematology 35:289-293.

McGovern, R.J. and McSorley, R. 1997. Physical methods of soil sterilization for disease management including soil solarization. Ch. 12, In: Environmentally Safe Approaches to Crop Disease Control, Eds. Rechcigl, N., A. and Rechcigl, J. E., CRC Lewis Publishers, Boca Raton, FL.

McSorley, R. 1999. Host suitability of potential cover crops for root-knot nematodes. Journal of Nematology 31: 619-623.

McSorley, R., Gallaher, R.N. 1992. Comparison of nematode population densities on six summer crops at seven sites in North Florida. Journal of Nematology 24: 699-706.

McSorley, R., Gallaher, R.N. 1993. Effect of crop rotation and tillage on nematode densities in tropical corn. Journal of Nematology 25: 814-819.
McSorley, R., Dickson, D.W., de Brito, J.A. 1994. Host status of selected tropical rotation crops to four populations of root-knot nematodes. Nematropica 24: 45-53.

McSorley, R., Dickson, D.W. 1995. Effect of tropical rotation crops on Meloidogyne incognita and other plant-parasitic nematodes. Journal of Nematology 27: 535-544.

McSorley, R., Gallaher, R.N. 1995. Cultural practices improve crop tolerance to nematodes. Nematropica, 25: 53-60.

Stapleton, J.J. 1991. Thermal inactivation of crop pests and pathogens and other soil changes caused by solarization. Chap. 3 In: Soil Solarization, DeVay, J.E., Stapleton, J.J., and Elmore, C.L., Eds., FAO Plant Production Paper 109, FAO, Rome.

Swift, M.J., Heal, O.W., Anderson, J.M. 1979. Decomposition in terrestrial ecosystems. In: Studies in Ecology, vol. 5. University of California Press, Berkley, CA, 372 pp.

Wang, K.-H., McSorley, R. 2003. Nematophagous fungi. Dept. of Entomology and Nematology, University of Florida, Gainesville, FL.

http://agroecology.ifas.ufl.edu/nematophagous $\%$ 20fungi/Beneficial\%20Soil\%20fungi.htm accessed 09-19-2007.

Wang, K.-H., McSorley, R., Marshall, A.J., Gallaher, R.N. 2004. Nematode community changes associated with decomposition of Crotalaria juncea amendment in litterbags. Applied Soil Ecology 27: 31-45.

Wang, K.-H., McSorley, R., Kokalis-Burelle, N. 2006. Effects of cover cropping, solarization, and soil fumigation on nematode communities. Plant and Soil 286: 229-243.

Weibelzahl-Fulton, E., Dickson, D.W., Whitty, E.B. 1996. Suppression of Meloidogyne incognita and $M$. javanica by Pasteuria penetrans in field soil, Journal of Nematology 28: 43-49. 1996. 